\title{
Academia's thoughts and graduates' opinions of education at university degree for translators and interpreters: is there a need for revisiting both concept and practice?
}

\author{
Anastasia A. Atabekova - Rimma G. Gorbatenko - Tatyana V. Shoustikova \\ - Carmen Valero Garces
}

DOI: 10.18355/XL.2018.11.01.22

\begin{abstract}
The reason for the present study topic is rooted in a thorny situation. On the one hand, there are centuries-long traditions and prolific research in the area of Translator and Interpreter education, both practice and research lay grounds for the stable training of the mentioned specialists. On the other hand, the third millennium has brought to smart life societies, intensive collaborations, harsh contradictions and ideological tensions into the multilingual and multicultural world. The changing and emerging contexts of interpreter and translator's professional activities challenge the current vision of the mentioned specialists' training background and skills, put on the agenda new requirements for those who are expected to act properly to respond to newly diversified societal needs. The research goal is to explore the aspects that might be subject matter for the anticipated revision of T/Is university-based education. The research methodology integrates qualitative and quantitate analysis and rests on theoretical and empirical activities. Materials for theoretical analysis involve publications on the issues under study. The research includes cluster and factor types of analysis to identify gaps between Academia, Industry, and Research regarding the quality of translating and interpreting in socially- focused settings. Statistical Package for the Social Sciences was used to process data. The research findings allow for drafting preliminary recommendations regarding revisiting T\&Is' training in the era of globalization.
\end{abstract}

Key words: philosophy of education, translator and interpreter training, third millennium environments for T/Is' training

\section{Introduction}

The Concept of Education for translators and interpreters (further T\&I) and mirroring practices were charting their path from ancient civilizations to modern society of digital knowledge. One can easily recall translation and interpretation schools that ran across the past centuries in China, Austria, Spain, Turkey, Egypt, Uruguay, France and other countries, as well. The above schools accumulated local philosophy and other countries' visions of interpreter and translator education. The second half of the 20th century gave birth to international and national professional organizations of translators and interpreters, laid grounds for a common understanding of philosophical thought on T\&I education principles, methods, standards for T\&I' institutional training and their professional codes of ethics. Degree programs for T\&I's have become common for European, American, Asian, Australian universities. Mutual recognition of university degrees in Translation and Interpreting got new impetus due to Bologna process. The UNO, European Commission, and European Parliament also contributed to disseminating promising practices and shaping core curriculum and competencies for T\&I education. The institutions have launched and foster network of universities that offer respective degree courses under the core curriculum principles, shared vision of the key competencies, a common principle of T\&I qualifications (EMT, 2017; EMCI, 2017; United Nations: the competitive language examination, 
2017).

Nonetheless, modern globalization and civilization development affect the Interpreter and Translator profession. The present research topic has been chosen because the second decade of the Third Millennium provides a sharp focus for increasing societal needs for interpreters and translators that engage in contemporary international cooperation development and public service provision. According to K. Rogers (2017), "the number of people employed in the translation and interpretation industry has doubled in the past seven years," and as for technology dominance of human translators, it just helps translators and interpreters improve their performance and does not seem to replace them successfully.

The current state of affairs confirms that interpreters and translators turn out to bear much stronger social responsibilities. Today T\&Is engage in public services on a much larger scale than some ten years ago, often act on the front lines of emergency situations, take part in problem-solving for global migration issues, stand to lend a helping hand in local or regional conflict zones (Atabekova et al., 2017).

On the other hand, the worldwide digital development of the smart society also contributes to changing the profile of translator or interpreter's job, as well.

The above leads to the research hypothesis that the mentioned situation might require revisiting the Concept of Education for Interpreters and Translators (further T\&I) due to existing gap among academic teaching/learning practices on the one hand, and research findings and graduates' needs, on the other hand.

The research goal is to explore the aspects that might be subject matter for the anticipated revision.

The goal can be reached through the following tasks:

- to study relevant literature to trace dynamics of Philosophical Thoughts and Concepts of Education across History towards its key modern features;

- to explore relevant literature to identify how the Concepts mentioned above of Education general features are embedded in the Concepts and Thoughts of Education for T\&I in today's realities;

- to glance at curricula description provided by universities that offer MA T\&I degree courses;

- to conduct a survey of graduates (with 3-5 years of work/research experience in the field) of university-based T\&I degree courses with the view to identify sensitive issues regarding equilibrium between Academia concept off T\&I's education content and client/ employer/market requirements graduate T\&Is should meet;

- to draft recommendations for revisiting Concepts and Thoughts of Education for T\&Is.

\section{Literature Review}

Concepts and Thoughts of Education in Historical Perspective: General Overview

Contemporary society witnesses' global transformation of civilization. It is an objective process that affects every aspect of human life, poses challenges and aspirations, brings positives and negatives into communities (Giddens, 2000).

Against the above background, scholars underline the societal importance of philosophical thought on education, point out that concept of education and its vision exert significant influence on building sustainable knowledge society (Zarevski, 2015) and research career development at the global level (Chigisheva et al., 2017).

Researchers cast light onto the open nature of Philosophical Thought on Education, its interdisciplinary nature and close connection with deontology of education, pedagogy, etc. (Hermann, 2015). Nonetheless, for the present research, it is relevant to define the general scope of the discipline under study for its further reference to education for 
T\&Is.

As D.C. Phillips and S. Harvey (2015) mention, philosophical thought on education traditionally refers to the study of the basic principles, purposes, process, the essence of education within broad societal and human mental framework. Moreover, the area under study explores definitions, concepts, methodologies used in education by policymakers, educators, administration, and faculty. Conceptual Philosophy of Education also explores particular trends or approaches by educators and policymakers about debates, deliberations and innovative assumptions about teaching within broad philosophical context.

Philosophers have produced invaluable input to the conceptual thought on education development; their work has contributed to shaping education concept and practice over the millennia.

From early masterpieces of Socrates and Plato (Plato, 2009) the importance of acquiring knowledge through various means was promoted, the values of learning through examining the world, interpreting and processing existing knowledge through discussion were cultivated in progressive communities.

Further on, across centuries, prominent philosophers in education tried to foster and enhance the preliminary shaped foundations of human-focused education for citizenship, through discovery and experience (Rousseau, 2003).

It is worth mentioning that among other things in the late 17th Century, John Locke in his prominent "Some Thoughts Concerning Education" mentioned the particular importance of an appropriate academic curriculum as a person was to a large extent a product of his education (Lock, 1692).

In the 20th Century, J. Dewey (1938) argued for the importance of "learning-bydoing," urged for avoiding teaching of "dead" facts, stressed the need to train skills and impart knowledge which helps students develop as human beings, professionals, citizens. R. Steiner (1937) developed similar approaches by emphasizing the education goal to balance intellect, feelings, heart, and practical skills to bringing up individuals who are efficient servants to society.

Following T. Kuhn's (1970) announcement of the social paradigm shift in the 20th century, we are experiencing transfer from second to third millennium thinking. It fosters shift in some trends, namely:

-from teacher-centered instructive to the learner-focused constructivist philosophy of education (Fosnot, 1996; Jonassen, 1991);

- towards Vygotsky's sociocultural theory of learning, which advocates for teacher's guidance to enable students to efficiently cope with real-life tasks thus acquiring complex skills and competencies (Vygotsky, 1978);

-towards a pragmatic approach to education that dates back to William James and Charles Peirce legacy and currently develops in line with the knowledge society requests for purposeful and transferable skills (Mounce, 1997).

Another point to be mentioned regarding the modern philosophy of education concerns deontology as it characterizes pedagogy's philosophical background, regulative side of the philosophy of education. Thus, as V. Rosic (2011) mentions, it is critical for every professional to adhere to moral principles. The support for this statement can be found in many papers on deontology in professional and higher education (see, for instance, Zandvoort et al., 2013). Educators lay special emphasis on the importance of developing students' sense of community, social responsibility for the well-being of others, for the good of their state (Berman, 1990).

Therefore, social responsibility and responsible professional conduct are the two essential sides of ethical aspects of education; both components are critical for proper education with no regard to any specific domain.

Furthermore, the paradigm shift in the philosophy of education is expected to result in revisited education systems that help future specialists feel confident and competitive

XLinguae, Volume 11 Issue 1, January 2018, ISSN 1337-8384, eISSN 2453-711X 
on the market and operate in concordance with standards of the corporate social responsibility.

The above provisions support the thesis on the current importance of research that focuses on the theoretical background and practical steps within the shift mentioned above being underway in various educational areas.

The next step of the present research is to identify how the thoughts mentioned above and concepts of general education trends are embedded in the Philosophy of Education for Translators and Interpreters.

Concepts and Thoughts on Education for Translators and Interpreters: Current State of Affairs in Research

The current state of affairs in education for translators and interpreters is far from providing a structured picture. The stakeholders in Translation and Interpretation community include diverse audiences. They range from university students and teachers, professional translators, and interpreters with university degree titles, towards people who act as translators and interpreters after passing some relevant qualification exams that lead to certification. The T\&Is community also incorporates digital technologies specialists who deal with machine translation and digital interpreting and web-localizers. Mention should be made about employers, as well (translation agencies, departments in corporate, public, government institutions, etc.). The representatives of the listed communities differ in their relation to relevant education and training scope, purposes, process, and outcomes.

Thus, educators are supposed to be aware of the above to implement diversified constructivist and pragmatic approaches to building and developing concepts and thoughts on T\&I education for diverse target audiences.

The awareness mentioned above is expected to be reflected in research and practice regarding T\&I education.

The analysis of relevant literature confirms that scholars strive to raise awareness of the academic community regarding the fact it is time for T\&I education to go social (Wolf, 2010) and to go beyond the Ivory Tower (Baer and Koby, 2003) as translation and interpreting are socially situated activities (Inghilleri, 2003). Thus there are strong and consistent advocates for modeling real-life contexts of interpreting and translating for educational purposes (Modelling the field of community interpreting: questions of methodology in research and training, 2011).

Researchers in the field of T\&I's education raises a question the role of formal theoretical knowledge that today is viewed as a mandatory element of the universitybased education. It does not mean the refusal of theoretical studies. As Vidal Claramonte mentions, there is a need for "new theoretical constructs, more attuned to contemporary problems" (Vidal Claramonte, 2013: 190).

Another point that can be found in research papers concerns stakeholders who have rather fragmented and

generalised vision of T\&I professional tasks and stumbling blocks that go beyond purely linguistic matters. Nonetheless, this angle of T\&I is still to be highlighted, the researchers underline the necessity to involve employers in T\&I research and education (Bendazzoli and Monacelli, 2016).

The about learner-centered individual approach in the Philosophy of T\&I education little can be found in research concerning particular systems (and not separate descriptions of sample activities). Scholars generalize activities and mention pair and small group work, guided translation exercises, projects (Johnson, 2003; Nord, 2005; Gouadec, 2007).

The constructivist and pragmatic approaches in research of the Philosophy of Education for T\&I are revealed through the distinction between T\&I's training and T\&I's education that is consistently underlined by D. Kiraly (2000) and his supporters. They view T\&I's training as the process of acquiring skills and techniques and T\&I's education as the process of acquiring relevant knowledge regarding future 
professional contexts, types of assignments, professional code of ethics, pathways to interact with peers, colleagues, clients, etc. in diverse social and cultural contexts.

Further, the issues related to collaborative learning come to Academia studies. Authors exploring the topic underline that collaborative construction in T\&I education should be viewed as a kind of positive development in T\&I education as the above format goes in line with the current nature of translation and interpretation as an industrialized team-based work (Kiraly, 2003).

Scholars also point out that it is time to revisit ethics and ideology in situations of conflict ((Re) considerando ética e ideología en situation de conflicto/(re)considering ethics and ideology in situations of conflict, 2014) to focus on the concepts of 'public service' and shift the focus from pure language to the social role of translators and interpreters. In this regard, there are voices to breathe new life into the concept of Professional Codes of Ethics for T\&I as there are obvious shortcomings regarding T\&I's societal roles and scenarios (McDonough, 2011). The above trends in research on T\&I education correlate with deontology regarding the domain under study.

Some authors draw specific attention to the development of educational aid concept concerning new emerging technologies that can put students into real translation world situations (House, 2000; Orlando, 2010).

Particular emphasis is laid on assessment and evaluation. Scholars mostly argue for a holistic approach to the procedure (Testing and assessment in translation and interpreting studies, 2009) and specify the importance of ongoing systemic evaluation and fragmented formal kind of procedure (Way, 2008).

The analysis of research papers most cited in the field of translation and interpreting studies makes it possible to conclude that Academia follows the general ideology of the Philosophical Thought of Education in research. Scholars put forward goals of developing learner-centered T\&I's education, fostering situated learning and case studies in T\&I's training, enhancing both theoretical backgrounds for training conceptual framework and practical measures and tools to turn academic framework of training to societal needs and realities.

On the other hand, the above-listed topics can be identified in line with potentially sensitive issues regarding deliberations on Academia curricula, first, and graduates' vision, second.

The next step is to glance at curricula description provided by universities that offer MA T\&I degree courses.

\section{Materials and Methods}

The research methodology integrated purely theoretical, applied analytical and empirical kinds of studies.

Desk research focused first on the Philosophical Thoughts of Education across History to map the concepts that bear current importance for the analysis of the state of affairs in T\&Is' education. Research materials included statements of prominent philosophers of the past.

Further studies aimed to understand ways through which the Concept mentioned above of Education general patterns are mirrored in the Concept of Education for T\&Is. Relevant papers (most sited in the field of translation and interpretation studies according to Scopus database) were brought into research focus and thoroughly examined.

The above review of most prolific researchers in the subject area under study led to preliminary assumptions on potentially sensitive issues regarding constraints between theory and practice within the T\&I's university-based training.

Next, the investigation tried to explore general trends in designing master's courses on translation and interpreting. Universities' curricula for T\&Is' education came into sharp focus. University selection criteria followed QS ranking methodology and

XLinguae, Volume 11 Issue 1, January 2018, ISSN 1337-8384, eISSN 2453-711X 
covered the analysis of T\&I's degree courses announced by the relevant universities. With 300 universities being included in the respective list, the research moved towards masterstudies.com. The portal which laid grounds for analysis of 468 courses on Master in Translation (2017) and 546 courses on Master in Interpreting (2017).

Only the programs of universities ranked in QS subject area under study were taken into account.

The glance at universities curricula in the subject area under study aimed to compare the announced curricula and training contents with modern research analysis standards, translation and interpretation industry requirements, academic approach to knowledge, skills, and competencies.

The next research step aimed to explore the situation from a contrary angle and focused on graduates' opinions regarding their university-based T\&I degree courses.

The survey techniques were applied as the current methodology of research in translation and interpreting confirms the importance of students/graduates/translators and interpreters' voices (Advances in interpreting research: inquiry in action, 2011).

Over one thousand online invitations to take part in the survey were sent through social media to translators and interpreters. The invitations kindly specified the focus on novice specialist in the field of Translation and interpretation industry and research. Finally, 240 respondents (MA programs graduates and Ph.D. students) were selected to produce equal proportions of different type of target audiences (translators, interpreters, and $\mathrm{Ph} . \mathrm{D}$. students in the field of translation or interpreting studies).

The survey engaged respondents from EU countries, China, Iran, South Korea, and Russia, with an equal proportion of graduates engaged in Research/professional T\&Is Industry, the proportion of respondents engaged in translation/ interpretation, and proportion of interpreters that specialize in consecutive/ conference interpreting. The respondents preferred not to disclose their data though they agreed to indicate their country of origin, affiliation to a concrete university and program, gender, age (2529), working/research experience length (3-5 years) after graduation. The above characteristics were used as variables for research.

The system of the online questionnaire was used for data collection. The respective survey was conducted on the grounds of needs analysis principles and included openended questionnaires on the following issues:

1. What are your current professional activities? (Choose from the list or add on your own):

-Ph.D. course on Translation/Interpretation

-Translation Industry

-Interpretation Industry (Consecutive/Conference/Both) - Underline the variant of your own.

2. What are the real world professional needs you could identify regarding your current professional activities (research/translation/ interpretation)?

3. What are skills (regarding your current professional activities) that you are lacking and consider necessary to mention?

4. What are possible reasons for the failures mentioned in question 3 ?

The statistics were used to check the graduates' opinions on T\&Is' degree courses regarding the training process, strategies, tactics, and materials used.

Cluster, factor, and discriminant types of analysis were applied to process the data through SPSS software.

\section{Results and Discussion}

\section{Universities Curricula for Master Courses for T\&Is at a Glance}

The review of university curricula for T\&I's education based on the selection criteria by QS ranking methodology and covered the analysis of T\&I's degree courses announced by those universities that enter the QS ranking for Modern Languages 
(2017), Arts and Humanities (2017), Linguistics (2017) (see the links to QS ranking lists on the mentioned subject area in the references list). Totally 300 universities are included in the list, though not of them provide exactly degree course on T\&Is.

Further, the attention was paid to the course descriptions on the programs under study that are provided by the portal masterstudies.com.

On-line search on the mentioned portal with the keywords Master in Translation (2017) amounts to 468 courses and search with the keywords Master in Interpreting (2017) reach 546 entries. Only programs that offer universities ranked in QS subject area under study were included into the list for further studies (see the links to the portal pages in the reference list).

The analysis of the T\&I degree course curricula announced on the masterstudies.com portal reveals that overwhelming majority of universities across continents strive to perform up-to-date regarding the university-based T\&I training contents. University programs look attractive regarding subjects lists that offer balanced combinations of core and optional disciplines, courses of theoretical and applied nature, strong focus on market needs depending on the degree course specialization, particular attention to CAT tools in translation and Interpreting, corpora studies for research purposes, etc. The co-authors of the present paper Prof Anastasia Atabekova (RUDN University, Russia) and Prof Carmen Valero Garcés (University of Alcala de Henares, Spain) have honor and pleasure to mention their didactic and administrative cooperation in balancing curricula of partner programs for Translation and Interpreting in Public Service. The list of core and optional subjects was settled and matched both the national standards of T\&I's education and international requirements specified by international employers and international professional associations (see the link to the course description in the reference list - UAH-RUDN COURSE ON TIPSI, 2017). A strong focus on balance of interests regarding Academia and Industry needs regarding the T\&Is' skills regarding language and culture support for public service provision has been one of the core principles of the above program design and implementation. The overall glance at universities curricula provided by official sites related to the analyzed courses confirms that T\&Is' degree courses designers follow the previously mentioned research findings and recommendations in the field under study. The universities shape their curricula in line with modern research analysis standards, in concordance with students' needs and translation and interpretation industry requirements regarding applied professional focus, integrated approach regarding interdisciplinary knowledge, skills, and competencies.

The data from the mentioned sources contribute to the happy and inspiring impression. However, due to diverse audiences engaged in T\&I's education and practice and new emerging contexts of professional activities, it is worth to view at the data from the angle of university graduates' opinions with some professional tenure in translation /interpreting industry or research.

\section{Survey of University Graduates' Opinions}

The survey of graduates' opinions regarding university-based T\&I degree courses was conducted on the grounds of needs analysis principles. The survey aimed to identify sensitive issues regarding equilibrium between university concept of T\&I's education content and client/ employer/market requirements they should meet. The open-ended questionnaires resulted in some clusters that feature concrete gaps between the academic vision of T\&I's education concept, on the one hand, and translation and interpreting studies or industry real needs respondents identified.

Table 1 shows gaps that were mentioned by T\&I's degree programs graduates who embarked on research career track (see Table 1 -drafted by the authors of the paper)

Table 1: Gaps between T\&I's education concept and real needs of translation and interpreting research studies

XLinguae, Volume 11 Issue 1, January 2018, ISSN 1337-8384, eISSN 2453-711X 


\begin{tabular}{|l|l|}
\hline Cluster & $\begin{array}{l}\text { Percentage of } \\
\text { respondents } \\
\text { mention the item }\end{array}$ \\
\hline $\begin{array}{l}\text { Need for practical experience to apply quantitative } \\
\text { analysis to research procedure }\end{array}$ & $67 \%$ \\
\hline $\begin{array}{l}\text { Need for professional skills regarding the use of } \\
\text { Statistical Package for Social Sciences }\end{array}$ & $51 \%$ \\
\hline $\begin{array}{l}\text { Need for Ph.D. students specific skills related to } \\
\text { drafting and publishing papers for international research } \\
\text { journals that are indexed in the international databases }\end{array}$ & $47 \%$ \\
\hline $\begin{array}{l}\text { Need to systemic skills to work with language corpora to } \\
\text { increase the number of samples relevant for research } \\
\text { purposes }\end{array}$ & $37 \%$ \\
\hline
\end{tabular}

It should be noted that the above percentage was not sensitive to a respondent's origin ( $p>0,02)$, affiliation with a concrete university ( $p>0,03)$, gender $(p>0,03)$.

The factor analysis was conducted to identify reasons for mentioned needs within the cluster.

Students mentioned the following reasons that led to the lack of skills listed in the cluster.

1st factor - students' failure to understand the importance of the mentioned skills (0.989); the item was mentioned by $54 \%$ of the graduates;

2nd factor -teachers' failure to explain the importance of the course (that focused on the skills in question) to the students (0.989); the item was mentioned by $99 \%$ of the respondents;

3rd factor - lack of students' awareness of the prospect career fields and relevant skills need and importance of the mentioned skills in further (0.651); the item was mentioned by $65 \%$ of the graduates.

$4^{\text {th }}$ factor - neither research supervisor nor Master course administration required extended large-scale empirical studies and allowed MA students to limit their degree papers with narrative comparison and further judgment over limited extracts of translation or interpreting practice examples $(0,413)$; the fat was specified by $42 \%$ of the respondents.

The discriminant analysis identified as statistically significant $\mathrm{PhD}$ program specialization $\left(\lambda=0,243, \chi^{2}=4,65, \mathrm{p}<0,01\right)$.

The above data enhance the understanding of the issue that A. Pym (2012) mentioned earlier. While considering drawbacks of current Ph.D. students training in translation or Interpreting Studies, he states such problems as the absence of consistent adherence to the research topic, use of vague and unstable terms, cringing at more prominent disciplines, lack of research quality.

Moreover, the data of discriminant analysis correlates with the concerns that recently ATISA Declaration has voiced (ATISA, 2008). The cluster and factor analysis data revealed that at least some universities pursue years-long practice of so-called philological and linguistic perspectives in translation and interpreting studies (Nida 1991), follow the understanding of master-level research work as the activity that requires extended review of literature and practical analysis of limited cases to support the research hypothesis and goals (Wong, 2016). Nonetheless, the modern trends in educational philosophy of knowledge-based society assume and require the researchers' exposure to open large-scale empirical data (Elken and Wollscheid, 2016). The present research data on Ph.D. students' opinions on their currents needs confirms the above thesis in the particular area of Translation and Interpreting Studies. Further, some respondents' comments on the lacking level of skills for publication in the international journals confirm that it is timely to think of a 
specialized course on the respective topic. Such a course is sure to go far beyond the general academic writing course that is offered by the overwhelming majority of university programs.

Table 2 shows gaps that were mentioned by T\&I's degree programs graduates who embarked on translation pathway (see Table 2-drafted by the authors of the paper).

Table 2: Gaps between T\&I's education concept and real needs of translation industry

\begin{tabular}{|l|l|}
\hline Cluster & $\begin{array}{l}\text { Percentage of respondents } \\
\text { that mention the item }\end{array}$ \\
\hline Need for practical skills in editing and proofreading & $52 \%$ \\
\hline $\begin{array}{l}\text { Need for advanced level of work with translation } \\
\text { memories }\end{array}$ & $44 \%$ \\
\hline Need for glossaries in particular specialized domain & $37 \%$ \\
\hline $\begin{array}{l}\text { Need to systemic skills to work with language } \\
\text { corpora to find and check specialized translation } \\
\text { equivalents }\end{array}$ & $31 \%$ \\
\hline
\end{tabular}

Regarding the cluster on the gaps between T\&I's education concept, and real needs of translation industry, respondents specified the following reasons for the lack of listed skills:

$1^{\text {st }}$ factor- excessive theorizing and narrative lecturing at the expense of vital debates on possible strategies and techniques in translation process $(0.491)$; the factor was mentioned by $49 \%$ of the respondents;

$2^{\text {nd }}$ factor -lack of student's awareness of the procedure complexity regarding systemic professional requirements for editing and proofreading in a real situation (0.491); the factor was mentioned by $49 \%$ of the respondents;

$3^{\text {rd }}$ factor - lack of information from the respective course leaders regarding the existing advanced CAT tools (beyond those uploaded in the university labs (0. 47); the factor was mentioned by $46,7 \%$ of the university graduates;

$4^{\text {th }}$ factor - lack of individual tasks and teacher's respective feedback $(0.44)$; the factor was mentioned by $43,7 \%$ of the university graduates;

$5^{\text {th }}$ factor - lack of real life team-based translation projects, lack of experience in shared responsibility and roles' distribution in a team (0.419); the factor was mentioned by $42 \%$ of the translators.

The respondents' opinions did not correlate with the respondents' origin ( $p>0,01)$, university affiliation Nonetheless, the discriminant analysis identified as statistically significant $\left(\lambda=0,234, \chi^{2}=4,05, \mathrm{p}<0,01\right)$ the workplace of the respondents: the mentioned factors were specified by respondents who work in large corporate business institutions.

The above data seems to be quite a new phenomenon; previous studies did not match specifically university graduates' skills disparities with market requirements from the angle of corporate vs. other forms of professional engagement.

Moreover, it is worth mentioning that D. Gouadec (2007) devoted specific chapters to specifics of translation profession and the translators' markets. Bearing in mind D. Couadec's (2007) thoughts and the present survey results the authors believe one of the next steps in their research might move into the respective direction.

Table 3 shows gaps that were mentioned by degree programs graduates who have become part of Interpreters' community (see Table 3-drafted by the authors of the paper).

XLinguae, Volume 11 Issue 1, January 2018, ISSN 1337-8384, eISSN 2453-711X 
Table 3: Gaps between T\&I's education concept and real needs of interpreting industry

\begin{tabular}{|l|l|}
\hline Cluster & $\begin{array}{l}\text { Percentage of respondents that } \\
\text { mention the item }\end{array}$ \\
\hline $\begin{array}{l}\text { Need for extended interpreting practice in } \\
\text { diverse professional contexts }\end{array}$ & $68 \%$ \\
\hline Need for extended memory exercises & $54 \%$ \\
\hline $\begin{array}{l}\text { Need for extended practice with bilingual } \\
\text { clichés }\end{array}$ & $47 \%$ \\
\hline $\begin{array}{l}\text { Need to skills to work with digital devices that } \\
\text { can help in interpreting }\end{array}$ & $38 \%$ \\
\hline
\end{tabular}

As for the cluster on gaps between T\&I's education concept and real needs of interpreting industry respondents mentioned the following factors:

$1^{\text {st }}$ factor-little attention to particular requirements regarding specific speech skills that are important or consecutive or conference interpreting (0.736); the item was mentioned by $73 \%$ of the interpreters

$2^{\text {nd }}$ factor - lack of awareness of real-life professional contexts of interpreting (0.678); the item was mentioned by $68 \%$ of the interpreters;

$3^{\text {rd }}$ factor - lack of information from the course teacher on the up-to-day devices that can support in interpreting (0.531); the item was mentioned by 53\% of the interpreters;

4th factor - lack of drills on information transformation (0.419); the item was mentioned by $42 \%$ of the interpreters;

$5^{\text {th }}$ factor- lack of pressure from the teacher on the class members to enhance continuous systemic training, (0.219); the item was mentioned by $22 \%$ of the interpreters.

The respondents' opinions did not correlate with their origin $(\mathrm{p}>0,03)$, gender $(\mathrm{p}>0,02)$, university affiliation $(\mathrm{p}>0,02)$.

The discriminant analysis identified as statistically significant the individual's engagement in consecutive/conference interpreting $\left(\lambda=0,243, \chi^{2}=4,015, p<0,001\right)$.

The above date correlates with previous research on interpreter's training (Pochhacker, 2010; Roderick, 2002) and sheds new light on graduates' interpreting program's needs (see the above list) as soon as they step into the industry that objectively confronts the Academia. Some general and methodological issues regarding these topics (Interpreting in the 21st century, 2002). Moreover, there is empirical research data on the specificity of interpreters' skills referring to various settings (Belenkova, 2017).

Further on, the questionnaire data confirms the importance of informing students of existing differences about interpreting skills and practical knowledge required within specific fields of interpreting (see, for instance, challenges for interpreting in medical or judicial settings).

All in all, the present survey results allow for arguing for stronger voices in favor of enhancing didactic tradition in the way of drafting concrete type of assignments for interpreter's training in particular professional contexts.

\section{Conclusion}

The project findings proved the relevance of the research hypothesis. The current state of affairs requires revisiting the Concept of Education for Interpreters and Translators due to the existing gaps that have been identified between academic teaching/learning practices on the one hand, and current research findings with respect to needs of university graduates being exposed to the T\&I industry and the market, on the other hand. 
The research outcomes have confirmed that there is a need for balance and synergy between Philosophical Thoughts on Education across History, Concepts of Education for T\&I in today's realities, and their practical implications.

Constraints have been identified through study between curricula description provided by universities that offer MA T\&I degree courses, on the one hand, and graduates' opinions of their T\&I degree courses (taking into account graduates' 3-5years of working experience/further studies in the field).

The research helped to identify sensitive issues regarding sought equilibrium between Academia concept of T\&I's education content and client/ employer/market requirements that novice specialists should meet.

In the course of studies T\&I students need systemic professional orientation, the university, and the degree course management should think over consistent policies and tools to relate every course to students' future career pathways, to explain and show through guided controlled practice and free learning activities the ways that diverse skills are applied. This vision will de facto introduce constructivism and pragmatism philosophy into contemporary educational settings for future translators and interpreters. Their training should be organized as both personalized and teambased education. Deliberations, debates, discussions are necessary for exchange and share of peers' experience and ideas, students' training for social interaction in professional settings. Abstract lecturing on general issues regarding translation and interpretation legacy of past centuries can be replaced by flipped lessons methodology that allows for personal learning and group interaction on the relevant topics.

Assignments deserve particular attention. They should reflect the real-life complexity of procedures and integrated diversity of activities. Guided discovery should play a systemic role in classroom and student independent learning management to train students' ability to transfer skills and provide optimal solutions to the challenges that novice specialists will be exposed to within T\&I industry or research area.

Modern smart society puts on the T\&Is education agenda the question on comprehensive digital tools integrated into the overall degree program content. It should not limit its syllabi to the course on CAT tools. T\&I Students need to be taught across the overall program how to use diverse and relevant corpus data, CAT tools and software to reach particular goals within specific research and practice domains. Special emphasis should be laid on possible ways to systemically enhance students' awareness of ways to conduct and integrate qualitative and quantitative studies in research activities.

The empirical studies confirmed the importance of translation and interpreting industry professionals' engagement into the relevant training. Given that, this should go beyond guest specialists' lectures and turn into a

There should be more hours in the curriculum for the guided independent training of interpreting and translation skills with further peer and practitioners' evaluation of the produced works.

The research results have made it possible to identify reasons, conditions, and techniques to renew approaches, ways and tools for university-based into interpreter and translators' training. Further research might move towards exploring personalized learning environments in the field of T\&Is' university-based training.

\section{Acknowledgements}

The publication was prepared with the support of the RUDN University program 5100.

\section{Bibliographic references}

ADVANCES IN INTERPRETING RESEARCH: INQUIRY IN ACTION. 2011. Nicodemus, B., Swabey, L. (Eds.). Netherlands-USA, Amsterdam/Philadelphia: John

XLinguae, Volume 11 Issue 1, January 2018, ISSN 1337-8384, eISSN 2453-711X 
Benjamins. 264 p. ISBN 9789027224477.

ATABEKOVA A.A. - STEPANOVA V.S. - UDINA N.N. - GORBATENKO O.G. SHOUSTIKOVA T.V. 2017. Interpreting in the context of refugee migration: emerging professional challenges and needs. In: XLinguae, vol. 10, issue 4, pp. 184195. ISSN 1337-8384. eISSN 2453-711X.

ATISA. 2008. Statement on Ph.D. training in Translation and Interpreting Studies. Available online: http://groups.yahoo.com/group/itit/message/2035

BAER, B.J.- KOBY, G.C. 2003. Beyond the Ivory Tower. Rethinking Translation Pedagogy. Amsterdam and Philadelphia: Benjamins. ISBN 9789027296375.

BELENKOVA, N. 2017. First Experience in Interpreting: Challenges and Solutions. In: Procedia - Social and Behavioral Sciences, n. 237, pp. 1242 - 1246. ISSN 18770428.

BENDAZZOLI, C. - MONACELLI, C. 2016. Addressing Methodological Challenges in Interpreting Studies Research. The UK, Newcastle upon Tyne: Cambridge Scholars Publishing. 280 p. ISBN-13 978-1-4438-9067-0.

BERMAN, S. 1990. Educating for Social Responsibility. In: Educational Leadership, n.11, pp. 75-80. ISSN 0013-1784.

CHIGISHEVA, O. - SOLTOVETS, E. - BONDARENKO, A. 2017. Functional Foreign Language Literacy for Global Research Career Development: Analysis of Standardized Open-Ended Interview Responses. In: XLinguae, vol. 10, issue 4, pp. 138-153. ISSN 1337-8384. eISSN 2453-711X.

DEWEY, J. 1938. Experience \& Education. USA, New York, NY: Kappa Delta Pi Lecture Series. ISBN 0684838281.

ELKEN, M. - WOLLSCHEID, S. (2016). The relationship between education and research: typologies and indicators. Norway, Oslo: Nordic Institute for Studies in Innovation, Research, and Education. ISBN 978-82-327-0182-7. ISSN 1892-2597 (online).

EUROPEAN MASTER'S IN TRANSLATION (EMT). 2017. Available online: https://ec.europa.eu/info/resources-partners/european-masters-translation-emt_en

EUROPEAN MASTERS IN CONFERENCE INTERPRETING (EMCI). 2017. Available online: http://www.emcinterpreting.org/

FOSNOT, C.T. 1996. Constructivism: Theory, Perspectives, and Practice. New York: Teachers College Press. ISBN-13 978-0807745700.

GIDDENS, A. 2000. Runaway World: How Globalization is Reshaping Our Lives. UK, London: Profile Books. ISBN 0415944872.

GOUADEC, D. 2007. Translation as a Profession. Netherlands-USA, Amsterdam, and Philadelphia: John Benjamins. ISBN 9027292515.

HERMANN, N. 2015. Risky thinking: the relation between philosophy and education. In: Educação e Pesquisa, São Paulo, v. 41, n. 1, pp. 217-228. ISSN 15179702.

HOUSE, J. 2000. Consciousness and the Strategic Use of Aids in Translation. In: Tirkkonen-Condit, S., Jääskeläinen, R. (Eds.). Tapping and Mapping the Processes of Translation and Interpreting: Outlooks on Empirical Research. Amsterdam and Philadelphia: Benjamins. 176 p. ISBN 9789027216427.

INTERPRETING IN THE 21ST CENTURY. 2002. Garzone, G. - Viezzi, M. (Eds.). Netherlands-USA, Amsterdam, and Philadelphia: John Benjamins. ISBN 9789027216496.

INGHILLERI, M. 2003. Habitus, field, and discourse. Interpreting as a socially situated activity. In: Target, vol. 15, n. 2, pp. 243-268. ISSN 0924-1884.

JONASSEN, D.H. 1991. Objectivism versus constructivism: do we need a philosophical paradigm? In: Educational technology research and development, N. 39, pp. 5-14. ISSN 1042-1629.

JOHNSON, J.E. 2003. Learning Through Portfolios in the Translation Classroom. In: Beyond the Ivory Tower. Rethinking Translation Pedagogy. Baer, B.J., Koby, J.S. 
(Eds.). Amsterdam: John Benjamins, pp. 97-116. ISBN 9789027296375.

KIRALY, D. 2000. A Social Constructivist Approach to Translator Education. Empowerment from Theory to Practice. Manchester: St. Jerome. 216 p. ISBN-10 1900650339.

KIRALY, D. 2003. From Instruction to Collaborative Construction. A Passing Fad or the Promise of a Paradigm Shift in Translator Education? In: Beyond the Ivory Tower. Rethinking Translation Pedagogy. Baer, B.J., Koby, J.S. (Eds.). Amsterdam: John Benjamins, pp. 3-27. ISBN 9789027296375.

KUHN, T.S. 1970. The structure of scientific revolutions. Chicago: University of Chicago Press. ISBN 0-226-45803-2.

KUHN, T.S. 1983. Commensurability, comparability, and communicability. SA: Proceedings of the Biennial Meeting of the Philosophy of Science Association, Symposia, and Invited Papers, vol. 2, pp. 669-688. ISSN: 02708647

LOCK, J. 1692. Some Thoughts Concerning Education. Available online: https://sourcebooks.fordham.edu/mod/1692locke-education.asp

MASTER IN TRANSLATION COURSES WORLD WIDE. 2017. Available online https://www.masterstudies.com/

MASTER IN INTERPRETING COURSES WORLD WIDE. 2017. Available online https://www.masterstudies.com/

MCDONOUGH, J. 2011. Moral Ambiguity: Some Shortcomings of Professional Codes of Ethics for Translators. In: JoSTrans: The Journal of Specialised Translation, n. 15 , pp. 28-49. ISSN 1740-357X.

MODELLING THE FIELD OF COMMUNITY INTERPRETING: QUESTIONS OF METHODOLOGY IN RESEARCH AND TRAINING. 2011. Kainz, C., Prunč, E., Schögler, R. (Eds.). Wien /Münster: LIT. ISBN 978-3-643-50177-6.

MOUNCE, H.O. 1997. The Two Pragmatisms: From Peirce to Rorty. UK, London: Routledge. ISBN 10: 0415152836.

NIDA, E. 1991. Theories of Translation. In: TTR: traduction, terminologie, rédaction, vol. 4, n.1, pp.19-32. ISSN 0835-8443 (imprimé).

NORD, C. 2005. Training Functional Translators. In: Training for the New Millennium. Pedagogies for Translation and Interpreting. Tennent, M. (ed.) Amsterdam and Philadelphia: Benjamins. 276 p. ISBN 9789027294715.

ORLANDO, M. 2010. Digital pen technology and consecutive interpreting: Another dimension in note-taking training and assessment. In: The Interpreters' Newsletter, vol. 15, pp.71-86. ISSN 1591-4127.

PHILLIPS, D.C. - HARVEY, S. 2015. Philosophy of Education. In: The Stanford Encyclopedia of Philosophy (Winter 2015 Edition). Zalta, E.N. (ed.). Available online: https://plato.stanford.edu/archives/win2015/entries/education-philosophy/

PLATO. 2009. The Republic. (Translated by Benjamin Jowett) Available on-line: http://classics.mit.edu/Plato/republic.html

PÖCHHACKER, F. 2010. The Role of Research in Interpreter Education. In: The International Journal for Translation \& Interpreting Research, vol. 2, n. 1. Available online: http://trans-int.org/index.php/transint/article/viewFile/80/62

PYM, A. 2012. Research Skills in Translation Studies: What we need training in. Available online: http://usuaris.tinet.cat/apym/online/research_methods/2012_research_skills.pdf

QS RANKING FOR MODERN LANGUAGES. 2017. Available online: https://www.topuniversities.com/university-rankings/university-subject-

rankings/2017/modern-languages

QS RANKING FOR LINGUISTICS. 2017. Available online: https://www.topuniversities.com/university-rankings/university-subjectrankings/2017/linguistics

QS RANKING FOR ARTS AND HUMANITIES. 2017. Available online:

XLinguae, Volume 11 Issue 1, January 2018, ISSN 1337-8384, eISSN 2453-711X 
https://www.topuniversities.com/university-rankings/university-subjectrankings/2017/arts-humanities

(RE)CONSIDERANDO ÉTICA E IDEOLOGÍA EN SITUACIONES DE CONFLICTO/(RE)CONSIDERING ETHICS AND IDEOLOGY IN SITUATIONS

OF CONFLICT. Valero Garcés, C. (Ed.). 2014. Alcalá: Universidad de Alcalá.

RODERICK, J. 2002. Conference Interpreting Explained. UK, Manchester: St Jerome Publishing. ISBN 9781900650571.

ROGERS, K. 2017. As the Earth feels ever smaller, demand for translators and interpreters skyrockets. CNBC, July 7. Available online: https://www.cnbc.com/2017/07/07/as-the-earth-feels-ever-smaller-demand-for-

translators-and-interpreters-skyrockets.html

ROSIĆ, V. 2011. Teacher's Deontology -The Basis of the Pedagogical Ethics. In: Informatologia, vol. 44, n. 2, pp. 142-149. ISSN 1330-0067.

ROUSSEAU, J.-J. 2003. Emile, or Education. USA, New York: Prometheus Books. ISBN 1-59102-111-1.

STEINER, R. 1937. Practical Course for Teachers. UK, London: The Rudolf Steiner Publishing Co. Available online: http://wn.rsarchive.org/Education/GA294/English/RSPC1937/PraTea_index.html

TESTING AND ASSESSMENT IN TRANSLATION AND INTERPRETING STUDIES. 2009. Angelelli, C.V., Jacobson, H.E. (Eds.). Amsterdam/Philadelphia: John Benjamins Publishing Company. 386 p. ISBN 978-90-272-3190.

UAH-RUDN COURSE ON TIPSI. 2017. AVAILABLE ONLINE. https://www.uah.es/export/sites/uah/es/estudios/.galleries/Archivosestudios/MU/Unico/AM040_3_5_4_E_COMUNICACION_INTERCULTURAL_Peo ples_Friendship_University_of_Russia_Ingles.pdf

UNITED NATIONS: THE LANGUAGE COMPETITIVE EXAMINATION (LCE). 2017. Available online: http://www.ata-divisions.org/ID/el-metwally-un-lce/

VIDAL CLARAMONTE, Á. 2013. Towards a New Research Model in Legal Translation: Future Perspectives in the era of Asymmetry. In: Linguistica Antverpiensia, n. 12, pp. 182-196. ISSN: 2295-5739.

VYGOTSKY, L.S. 1978. Mind in society: The development of higher psychological processes. Cole, M., John-Steiner, V., Scribner, S., Souberman, E. (Eds. and Trans.). Cambridge, MA: Harvard University Press. ISBN 9780674576292.

WAY, K. 2008. Systematic Assessment of Translator Competence: In Search of Achilles' Heel. In: Translator and Interpreter Training. Issues, Methods and Debates. Kearns J. (Ed.). London: Continuum, pp. 88-103.

WOLF, M. 2010. Translation 'Going Social'? Challenges to the (Ivory) Tower of Babel. In: MonTI Applied Sociology in Translation Studies/Sociologia aplicada a la Traducció, vol. 2, pp. 29-46. ISSN 1889-4178.

WONG, L. 2016. Where Theory and Practice Meet: Understanding Translation through Translation. UK: Cambridge Scholars Publishing. ISBN 1443899127.

ZANDVOORT, H. - BØRSEN, T. - DENEKE, M. - BIRD, S.J. 2013. Editors' Overview - Perspectives on Teaching Social Responsibility to Students in Science and Engineering. In: Science and Engineering Ethics, vol. 19, n. 4, pp. 1413-1438. ISSN 1353-3452, 1471-5546.

ZAREVSKI, D. 2015. Role of Educational Policies and Philosophical Thought on Education in Building Functional, Stable and Prosperous Knowledge Society. In: New Balkan Politics, vol.17, pp.51-69. ISSN 1409-8709.

Words: 6984

Characters: 50364 (27,98 standard pages)

Prof. Anastasia A. Atabekova, Dr. Sc.

Law Institute 
Foreign Languages Department

Peoples' Friendship University of Russia - RUDN University

6 Miklukho Maklay st.

117198 Moscow

Russia

aaatabekova@gmail.com, Atabekova_aa@pfur.ru

Assoc. Prof. Rimma G. Gorbatenko, $\mathrm{PhD}$

Law Institute

Foreign Languages Department

Peoples' Friendship University of Russia - RUDN University

6 Miklukho Maklay st.

117198 Moscow

Russia

gorbatenko_rg@pfur.ru

Prof. Tatyana V. Shoustikova, Dr. Sc.

Faculty for Pre-University Training

Department of Russian Language №2

Peoples' Friendship University of Russia - RUDN University

6 Miklukho Maklay st.

117198 Moscow

Russia

shoustikova_tv@pfur.ru

Prof. Carmen Valero Garces, $\mathrm{PhD}$

Facultad de Filosofía y Letras, Departamento de Filología Moderna

University of Alcala de Henares

Plaza De San Diego, s/n.

28801, Alcalá de Henares, Madrid

Spain

carmen.valero@uah.es 